\title{
Fake Popeye Muscles. Soft Tissue Granulomas Secondary to Intramuscular Synthetic Oil Injections in Bodybuilding. Case Series and a Literature Review.
}

\author{
Sultan AlShaqsi*, Mohammad A Qader Ali and Taimoor Albulushi \\ Khoula Hospital, Ministry of Health, Sultanate of Oman, University of Toronto, Canada
}

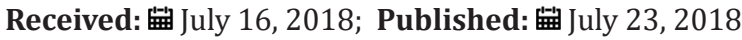

*Corresponding author: Sultan AlShaqsi, Khoula Hospital, Ministry of Health, Sultanate of Oman, Senior Resident, Plastic and Reconstructive Surgery, University of Toronto, Canada

\section{Introduction}

The administration of Site Enhancing Oils (SEO) is a wellknown illegal practice in sports that require significant muscle bulk such as bodybuilding [1,2]. This practice has been associated with significant health effects. The side effects from such practices appear decades after the initial injections and the most destructive form is chronic granulomas. This paper reports five cases of pathological massive muscle granulomas that required extensive surgical excision among amateur bodybuilders in the Sultanate of Oman. The article reviews the history of SEO in bodybuilding, pathophysiology, clinical and radiological assessment and finally management. This case series exemplifies the significant health consequences from recreational sport practices.

\section{Case Reports}

This paper reports five cases of large granulomas secondary to intramuscular injections of SEO that presented to Khoula Hospital in the Sultanate of Oman between 2015-1017. All patients consented for the use of their de-identified data for research purposes. Medical records were reviewed for demographic and clinical details.

\section{Discussion}

The first case report of intramuscular injections of inert material was reported in 1894 [1,3,4]. The oil injection was used to treat muscle spasm. Since then the practice has widely been expanded and used in shape-enhancing among bodybuilders without rigorous testing or reporting of potential side effects. There are currently only four materials approved by the US Food and Drug Administration (FDA) for medical use as injections [5] These include Hydrolaunic acid, Hydroxyapatite, Poly-L-Lactate Acid (PLLA) and collagen [4]. However, there is a wide spread of organic and synthetic materials that have been reported to be used off-label. Purified oils such as (soy oil, safflower oil, sesame oil and purified long and medium chain emulsions have been marketed by pharmaceutical companies as natural substitutes for anabolic steroids in muscle enhancing practices such as bodybuilding. The German bodybuilder Christopher T Clark was the first professional bodybuilder to market the synthetic oil Esiclene for recreational muscle injections [1,4,6]. He first marketed the formula in 1996 under the name Synthol and then renamed Syntherol with numerous formulations since then. Synthol is site enhancement oil, comprised of ( $85 \%$ oil, $7.5 \%$ lidocaine, $7.5 \%$ alcohol) [4]. In fact, Synthol has been used for years by professional bodybuilders those want to enhance the appearance of lagging muscles before competitions $[1,4]$. Synthol takes effect almost immediately, making it literally the fastest way to get the desired muscle size and shape, compared to anabolic steroids that takes time to work [4-7]. The Synthol epidemic is largely driven by a huge increase in usage in countries like Brazil, Argentina and Columbia, and it is legal to buy through the internet $[1,3]$ (Table 1 ).

Table 1: Details of case series of intramuscular granulomas from SEO.

\begin{tabular}{|c|c|c|c|c|c|c|c|}
\hline Case & Age & $\begin{array}{l}\text { Material } \\
\text { injected }\end{array}$ & $\begin{array}{c}\text { Chief } \\
\text { complaint }\end{array}$ & $\begin{array}{l}\text { Time interval } \\
\text { to presentation }\end{array}$ & Management & Dimensions & Pathology \\
\hline 1 & $40 \mathrm{M}$ & Synthol & $\begin{array}{l}\text { Bilateral } \\
\text { biceps } \\
\text { swelling and } \\
\text { deformity }\end{array}$ & 16 years & $\begin{array}{c}\text { Surgical } \\
\text { debulking }\end{array}$ & $\begin{array}{l}\text { Right side: } 7.2 \mathrm{x} \\
5.5 \times 3.2 \mathrm{~cm} \\
\text { Left: } 7.5 \times 5.2 \mathrm{x} \\
\quad 3 \mathrm{~cm}\end{array}$ & $\begin{array}{l}\text { Fibro-fatty collagenous tissue and } \\
\text { skeletal muscle fibres with extensive } \\
\text { cells surrounding vacuolated empty } \\
\text { spaces associated with Calcification and } \\
\text { chronic inflammatory lymphatic infiltrates } \\
\text { consistent with granulomas }\end{array}$ \\
\hline
\end{tabular}




\begin{tabular}{|c|c|c|c|c|c|c|c|}
\hline 2 & $45 \mathrm{M}$ & Synthol & $\begin{array}{l}\text { Bilateral } \\
\text { biceps and } \\
\text { triceps } \\
\text { swelling and } \\
\text { deformity }\end{array}$ & 14 years & $\begin{array}{c}\text { Surgical } \\
\text { debulking of } \\
\text { biceps masses }\end{array}$ & $\begin{array}{c}\text { Right: } \\
9 \times 6.5 \times 2 \mathrm{~cm} \\
\text { left: } \\
10.5 \times 6.3 \times 3 \mathrm{~cm}\end{array}$ & Granulomas \\
\hline 3 & 43 & Synthol & $\begin{array}{l}\text { Bilateral } \\
\text { biceps } \\
\text { and calf } \\
\text { swelling and } \\
\text { deformity }\end{array}$ & 15 years & $\begin{array}{c}\text { Surgical } \\
\text { debulking of } \\
\text { biceps and calf } \\
\text { masses } \\
\text { (two stage) }\end{array}$ & $\begin{array}{c}\text { Biceps: } \\
\text { Right: } 10 \times 6 \times 2 \\
\text { cm } \\
\text { Left } \\
10.4 \times 6.2 \times 3 \mathrm{~cm} \\
\text { Calf: right } \\
5 \times 3.2 \times 2.1 \\
\text { Left } 4.7 \times 3.2 \times \\
1.8 \mathrm{~cm}\end{array}$ & Granulomas \\
\hline 4 & $42 \mathrm{~m}$ & Synthol & $\begin{array}{l}\text { Bilateral } \\
\text { biceps } \\
\text { swelling and } \\
\text { deformity }\end{array}$ & 17 years & $\begin{array}{l}\text { Surgical } \\
\text { debulking }\end{array}$ & $\begin{array}{c}\text { Right } \\
14.5 \times 14 \times 7 \mathrm{~cm} \\
\text { left } \\
13 \times 13 \times 6\end{array}$ & Granuloma \\
\hline 5 & $43 \mathrm{M}$ & Synthol & $\begin{array}{l}\text { Bilateral } \\
\text { biceps } \\
\text { swelling and } \\
\text { deformity }\end{array}$ & 15 years & $\begin{array}{l}\text { Surgical } \\
\text { debulking }\end{array}$ & $\begin{array}{c}\text { Right } \\
\text { | 16x12x3 } \\
\text { left } \\
16 \times 10 \times 4\end{array}$ & Granuloma \\
\hline
\end{tabular}

The SEO are believed to add to muscle volume by creating an inflammatory response that leads to hypertrophy of muscle fibres. Some have also speculated that SEO cause significant scar tissue that adds to muscle volume permanently [4]. Such practice has adverse health effects, which would include immediate post injection pain and tenderness. Irregularity and contour deformities particularly if the SEO is injected non-uniformly or the same site has repeated injections. Devastating intravenous injections of SEO leading to cardio-respiratory compromise has been reported $[4,6]$. However, the most common side effect is long-term chronic granulomatous disease such as the cases reported in this series. Radiologically such masses should be assessed in a similar protocol to that of soft tissue swelling. MRI is the gold standard modality in such cases. It provides excellent soft tissue visualization and could aid with surgical plane of dissection planning [4].

The histopathologic changes related to SEO use have been studied in detail for more than 100 years and defined as a sclerosing lipogranulomatosis since 1950 [4,8]. This is a classical foreign body reaction with granulomas encapsulating oil consisting of foreign body Langerhans cells surrounded by fibrosis. Calcifications and atrophy of underlying muscle is prominent features. Skin and subcutaneous tissues can be involved adding to the complexity of any surgical procedure required to excise such masses. Symptomatic masses can be debulked surgically. Multiple stages might be required depending on the size, infiltrative and destructive nature of the granuloma. Soft tissue coverage of the defect is a critical consideration in cases that have compromised cutaneous layers. Local, regional and distant free musculocutaneous flaps might be needed. The residual granulomatous bed is hostile to simple skin grafts. Outcomes from repeated debulking leads to functional and esthetic losses. Very commonly the underlying muscle fibers are atrophied and difficult to separate from pathological tissue during granuloma excision. Contour irregularities after repeated debulking procedures can be esthetically unpleasing (Figures 1-6).

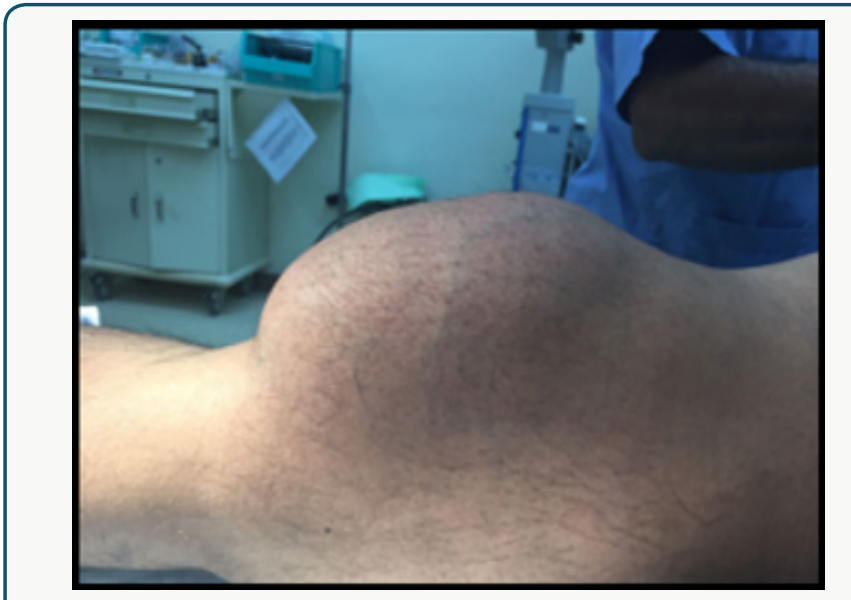

Figure 1: Significant biceps irregular mass from SEO injections.

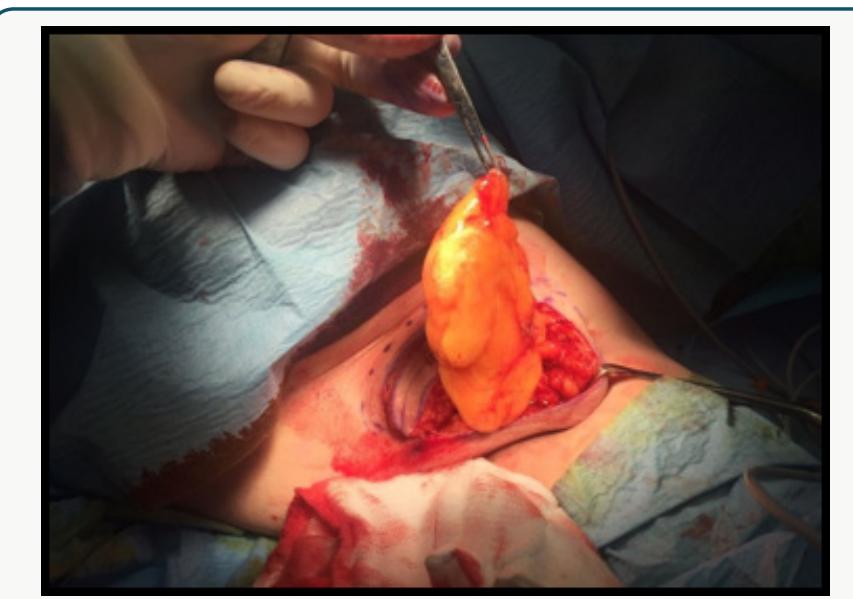

Figure 2: Intraoperative view showing fibrofatty granuloma. 

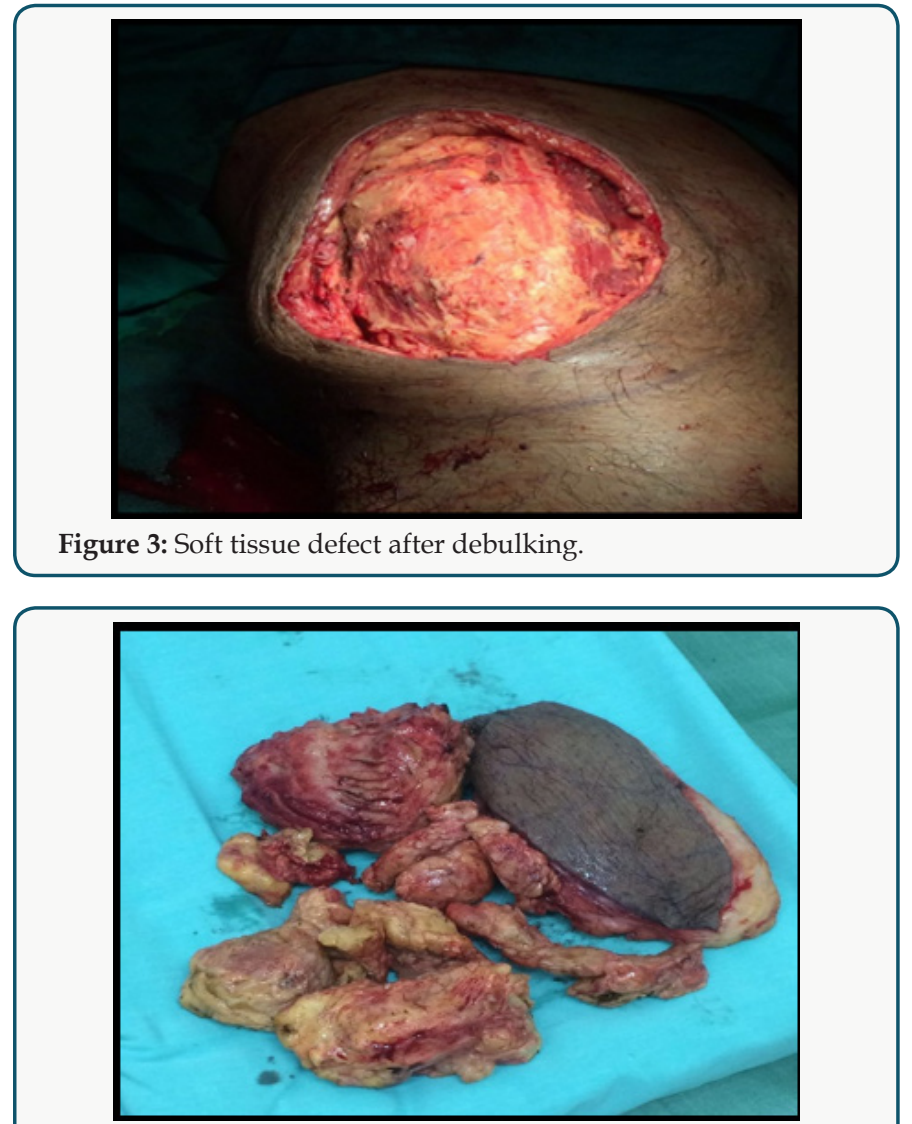

Figure 4: Excised granuloma from bilateral biceps.

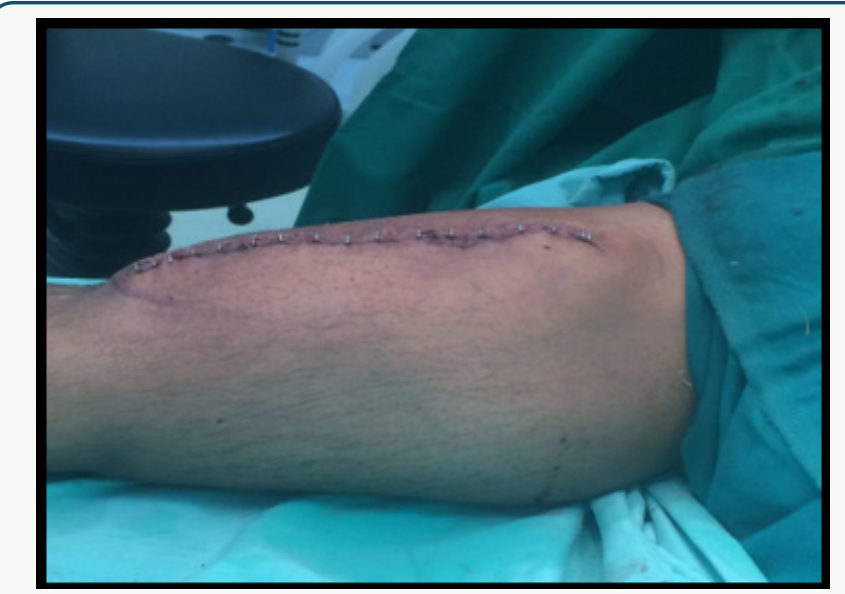

Figure 5: Immediate post-operative photo.

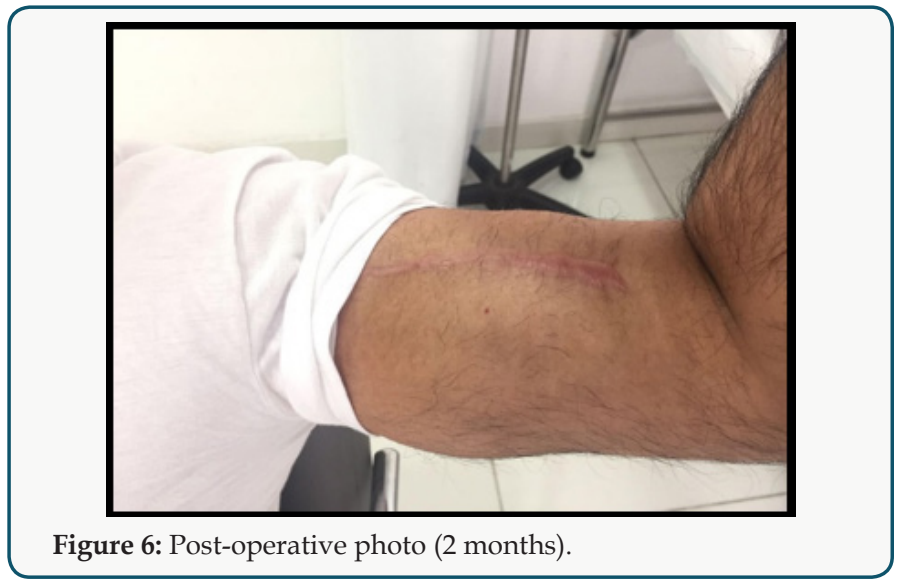

\section{Conclusion}

Sporting and healthcare authorities should join efforts to enhance the awareness of athletes to the dangers of inappropriate use of muscle enhancing substances. This series highlight the devastating long-term effect from such use.

\section{References}

1. Hall M, Grogan S, Gough B (2016) Bodybuilders accounts of synthol use: The construction of lay expertise. In: Chemically Modified Bodies: The Use of Diverse Substances for Appearance Enhancement.

2. Pupka A, Sikora J, Mauricz J, Cios D, Plonek T (2009) The usage of synthol in the body building. Polim Med 39(1): 63-65.

3. Ghandourah S, Hofer MJ, Kieling A, El Zayat B, Schofer MD (2012) Painful muscle fibrosis following synthol injections in a bodybuilder: A case report. J Med Case Rep 6: 248.

4. Schäfer CN, Hvolris J, Karlsmark T, Plambech M (2012) Muscle enhancement using intramuscular injections of oil in bodybuilding: Review on epidemiology, complications, clinical evaluation and treatment. European Surgery - Acta Chirurgica Austriaca 44(2): 109115 .

5. Banke IJ, Prodinger PM, Waldt S, Weirich G, Holzapfel BM, et al. (2012) Irreversible muscle damage in bodybuilding due to long-term intramuscular oil injection. Int J Sports Med 33(10): 829-834.

6. Juel J, Vestergaard Grejsen D, Pareek M (2017) Long-term adverse effects of intramuscular oil injection. BMJ Case Reports.

7. Figueiredo VC, Da Silva PRP, Trindade RS, De Rose EH (2011) Cosmetic doping: The problems of intramuscular application of oils. Revista Brasileira de Medicina do Esporte.

8. Brennan BP, Kanayama G, Pope HG (2013) Performance-enhancing drugs on the web: A growing public-health issue. Am J Addict 22(2): 158-161. 
(C) (i) This work is licensed under Creative To Submit Your Article Click Here:

Submit Article

DOI: 10.32474/OSMOAJ.2018.01.000120

$\begin{gathered}\text { Orthopedics and Sports Medicine } \\ \text { Open Access Journal }\end{gathered}$
Assets of Publishing with us
- Global archiving of articles
- Immediate, unrestricted online access
- Rigorous Peer Review Process
- Authors Retain Copyrights
- Unique DoI for all articles

